J. Product. \& Dev., 16(3):435 - 457(2011)

\title{
INCREASING STORAGE LIFE OF BALADY LIME FRUITS BY USING SOME PASSIVE AND ACTIVE MODIFIED ATMOSPHERE TREATMENTS.
}

O. A. I. Zagzog ${ }^{1}$; S. M. El-Hefnawi ${ }^{2}$ and F. MS. Mohsen ${ }^{2}$

1. Plant Production Department (Hort.), Efficient Productivity Inst., Zagazig University, Egypt.

2. Horticulture Department, Faculty of Agriculture, Zagazig University, Egypt

\section{ABSTRACT}

Five passive and active modified atmosphere (MA) treatments; i.e., 1- Non MA as control (packing in plastic nits as traditional practice), 2- Passive MA without additions, 3- Passive MA with adding $25 \mathrm{~g}$ wetted $\mathrm{Ca}(\mathrm{OH})_{2}$ per sealed package, 4- Active $\mathrm{MA} 10 \%$ $\mathrm{O}_{2}+3 \% \mathrm{CO}_{2}$ and 5- Active $\mathrm{MA} 10 \% \mathrm{O}_{2}+6 \% \mathrm{CO}_{2}$ were applied prior to cold storage of Balady lime fruits for periods of 30, 60, 90 or 105 days at $12 \pm 1^{\circ} \mathrm{C}$ and $90-95 \%$ relative humidity. Fruits were subjected to active and passive MA in tightly sealed carton boxes. After cold storage, fruits of all treatments were hold for 5 days at 20 ${ }^{\circ} \mathrm{C}$ and $60-70 \%$ relative humidity as shelf period. The target of such research was to clarify effects of modified atmosphere treatments, cold storage periods and their interactions on fruit storability and its quality after cold storage periods and after shelf life during 2010 and 2011 seasons.

Fruit samples taken after the tested cold storage and after 5 day's shelf life period exhibited that advancing storage period caused progressive increments in chilling injury index (CII), fruit decay \% (FD\%), fruit weight loss percentage (FWL \%); peel color index (PCI), juice TSS \%, Juice \% as well as technological index (TI) and TSS / acid ratio. While, juice contents of vitamin $C$ and acidity $\%$ as well as pulp firmness after cold storage and after shelf life period were gradually decreased with prolonging the cold storage period.

Generally, all tested modified atmosphere treatments reduced chilling injury index, fruit weight loss percentage, fruit firmness, juice $\%$, juice TSS, juice acidity \% and TI. Simultaneously, they increased fruit decay\%, peel color index as well as TSS/ acid ratio, but, did no significantly affect vitamin $C$ content in fruit juice.

Generally, make possible to recommend storage Balady lime fruits (in tight sealed carton boxes at rate of $190 \pm 10 \mathrm{~g}$ fruits/ liter) under passive MA with adding $25 \mathrm{~g}$ wetted $\mathrm{Ca}(\mathrm{OH})_{2}$ per package treatment for 60 days at $12 \pm 1^{\circ} \mathrm{C}$ and $90-95 \%$ relative humidity. This 
combination treatment minimized CII and FD \% after storage and kept fruits in good quality during the subsequent 5 days shelf period at $20^{\circ} \mathrm{C}$ and $60-70 \% \mathrm{RH}$.

Key words: Cold storage, passive \& active modified atmosphere, Balady lime fruits, chilling injury index.

\section{INTRODUCTION}

Balady lime (Citrus aurantifolia Swing) is one of the most important citrus cultivars. In Egypt, lemon trees occupied $43688 \mathrm{fed}$ produced 321281 tons. (Statistics of the Ministry of Agric.by Economic Affairs Sector 2009, Egypt).

Egyptian consumer prefers lime than lemon due to its high acidity and fruit size. There is a constant demand for Balady lime fruits throughout the year for local consumption and for exportation. Growers tried to apply some agricultural treatments such as fastening to prolong resulted in harmful effects on trees. So, cold storage of harvested fruits was the alternative way to prolonging its occurrence.

Modified atmosphere packing (MAP) treatments reduced chilling injury (CI) in limes and grapefruit (Wardowsky et al., 1973); in citrus fruits (Porat et al., 2004); in Fuerte avocado (Meir et al., 1998) and in mango (Pesis et al., 2000)

Also, modified atmosphere decreased fruit decay (Jitender et al., 2003, on guava; Artés-Hernández et al., 2006 on table grapes; Harb et al., 2006 on sweet cherries and Gad, 2008 on guava). The two last authors added that decay was increased gradually with advancing cold storage and shelf life periods.

Storing fruits of horticultural crops under modified atmosphere decreased fresh weight loss of table grapes (Martines-Romero et al., 2003); guavas (Pereira et al., 2004); apples (Rocha et al., 2004); cherries (Harb et al., 2006); date fruits (Mortazavi et al., 2007) and banana (Kudachikar et al., 2011). While fresh weight loss was higher with MA treatments than control after 2 or 3 days shelf life of guavas (Gad, 2008).

In addition, storing fruits under modified atmosphere preserved better colour of guava fruits (Pereira et al., 2004) ; apples (Rocha et al., 2004) ; cherries Harb et al., 2006) and strawberries (Aday, et al., 2011). Peel color index of guava fruits was gradually increased with the advance in cold storage and shelf life periods ( $\mathrm{Gad}, 2008)$. Also, MA conditions preserved better firmness respecting apples (Rocha et al., 2004); guavas (EL-Hefnawi et al., 2008), sweet cherries (Golias et al., 2010) and strawberries (Aday et al., 2011).

Total soluble solids percentage were decreased under MA conditions (Pal et al., 2005 on guavas and Kudachikar et al., 2011 on 'Robusta' banana). Golias et al., (2010) on sweet cherries and Viskelis et al., (2011) on apples reported that TSS of fruit did not significantly affect by different modified atmospheres. 
However, increasing storage period increased TSS\% in Andean blackberry (Sora et al., 2006) and guavas (Gad, 2008) fruits after cold storage and shelf life.

Ascorbic acid content in fruits was decreased with increasing storage duration under modified atmosphere (EL-Hefnawi et al., 2008 on guavas and Ahmed et al., 2007 on oranges). Anyhow, Viskelis et al., (2011) on apples reported that vitamin $\mathrm{C}$ content was decreased under modified atmosphere treatments.

Total acidity was reduced with increasing storage period under modified atmosphere conditions (Jitender et al., 2003 on guava and Sora et al., 2006 on Andean blackberry). Also, MA treatments caused gradual decrease in acidity content in guava fruits with the advance in cold storage period and during shelf life (EL-Hefnawi et al., 2008).

The main purpose of the current study was to evaluate the effectiveness of some passive and active modified atmosphere treatments under different cold storage periods to prolong storability and subsequent shelf life period of Balady lime fruits (Citrus aurantifolia Swing).

\section{MATERIALS AND METHODS}

This study was carried out during 2010 and 2011 seasons at the Post-harvest Laboratory, Horticulture Department, Faculty Agriculture, Zagazig University to evaluate the effectiveness of some modified atmosphere treatments prior to cold storage periods (30, 60, 90 and 105 days) for enhancing storability and the subsequent shelf life of Balady lime fruits.

Balady lime (Citrus aurantifolia Swing) fruits were used from similar trees aged 20 years old grafted on sour orange rootstock, grown in loamy soil at $5 \times 5$ meters apart. Fruits were purchased from a private orchard at El-Adllia, Blbies district, Sharkia Governorate, Egypt. Fruits were harvested at $1^{\text {st }}$ January during green ripe stage. The fruits were picked using small clippers and packed in carton boxes and directly transferred to the laboratory. Then, fruits were washed, air dried and rechecked for any defects. Characteristics of the used fruits just prior subjecting to the experimental treatments are shown in Table A.

Table A: Characteristics of Balady lime fruits before cold storage treatments

\begin{tabular}{|c|c|c|c|c|c|}
\hline Parameters & $\begin{array}{c}1^{\text {st }} \\
\text { Season }\end{array}$ & $\begin{array}{c}2^{\text {nd }} \\
\text { Season }\end{array}$ & Parameters & $\begin{array}{c}1^{\text {st }} \\
\text { Season }\end{array}$ & $\begin{array}{c}2^{\text {nd }} \\
\text { Season }\end{array}$ \\
\hline Pulp firmness $\left(\mathrm{kg} / \mathrm{cm}^{2}\right)$ & 0.748 & 0.790 & Juice pH & 2.77 & 2.72 \\
\hline Juice, \% & 30.0 & 29.8 & Juice acidi & 8.97 & 9.01 \\
\hline Volun & 315 & 310 & $\begin{array}{l}\text { Juice vit. C (mg/ } 100 \\
\text { cm }^{3} \text { juice) }\end{array}$ & 65.7 & 61.2 \\
\hline Juice TSS , \% & 10.7 & 10.5 & TSS/Acid ratio & 1.19 & 1.15 \\
\hline
\end{tabular}


The experimental design was factorial experiment between five modified atmosphere applications and four cold storage periods in completely randomized design, in three replicate, each replicate contained 500 grams fruits. So, the experiment was implicated 20 interaction treatments.

Fruits of all MA treatments, except of control treatment, were packed in sealed carton boxes at rate of $190 \pm 10 \mathrm{~g}$ fruits/ liter. Polyethylene bags were used to tight seal boxes. Modified atmosphere treatments were applied just before cold storage applications. However, the tested five modified atmosphere (MA) treatments were as follows:

1. Packing in plastic nets (control).

2. Passive MA without additions.

3. Passive MA with adding $25 \mathrm{~g}$ wetted $\mathrm{Ca}(\mathrm{OH})_{2}$ per sealed package.

4. Active MA $10 \% \mathrm{O}_{2}+3 \% \mathrm{CO}_{2}$.

5. Active MA with $10 \% \mathrm{O}_{2}+6 \% \mathrm{CO}_{2}$.

The four examined cold storage periods were 30, 60, 90 and 105 days. Fruits were stored at $12 \pm 1^{\circ} \mathrm{C}$ and $90-95 \%$ relative humidity. After cold storage fruits were hold for 5 days in an incubator at $20^{\circ} \mathrm{C}$ and $60-70 \% \mathrm{RH}$ (similar to supermarket conditions) to determine the effects on shelf life.

\section{Data recorded:}

Samples for each treatment were randomly taken after the tested cold storage periods of 30, 60, 90 and 105 and the remained fruits of each treatment were used to detect shelf life determinations. However, evaluation of treatment effects after cold storage and shelf life was implicated fruit exclusion attributes and fruit quality parameters as follows:

\section{Discarded Fruits Attributes:}

They were included:

1. Chilling injury index (CII): Chilling injury symptoms were included pitting, staining and necrotic areas on fruit peel (Sanchez-Ballesta et al., 2003). It was assessed according to the following index: $0=$ without decay; $2=$ spot decay; $4=25-50 \%$ decay; $8=>50 \%$ decay.

2. Fruit decay percentage (FD \%): It was determined as percentage of rotted fruits from the total fruits of each replicate.

II. Other fruit quality parameters:

They were included fruit physical and chemical properties of peel, pulp and juice of fruits as follows:

1. Fruit weight losses percentage (FWL \%) : Fruits were weighed just before and after cold storage treatments and the 5 days of shelf life, and then FWL \% was calculated.

2. Peel color index (PCI): Fruits color after each treatment was determined according to the following index: $1=100 \%$ green; $2=<25 \%$ yellow; $3=26$ $50 \%$ yellow and $4=>50 \%$ yellow. 
3. Pulp firmness: Five fruits for each replicate were used to determine pulp firmness as $\mathrm{kg} / \mathrm{cm}^{2}$. A push pull Dynamometer (Model FD 101) was used in this concern.

4. Juice percentage: The extracted juice of random fruit samples of each replicate was weighted and juice content was expressed as percent of fruit weight $(\mathrm{w} / \mathrm{w})$.

5. Juice total soluble solids percentage (TSS \%): It was determined using a hand refractometer.

6. Ascorbic acid (Vit.C) content in juice: It was determined as milligrams ascorbic acid / $100 \mathrm{ml}$ fruit juice using the procedures which described by Lucass (1944).

7. Juice total acidity (\%): It was determined by titration against $0.1 \mathrm{~N}$ sodium hydroxide in presence of phenolphthalein dye according to the method described by A.O.A.C. (1980).

8. Technological index( $\boldsymbol{T I}$ ): It was determined using the following equation:

$\mathrm{TI}=(\mathrm{TSS} \% \mathrm{X}$ juice $\%) / 100$. Technological index variable is an important indicator for citrus industry. Higher values of TI mean better quality for juice manufacture (Chitarra and Chitarra, 1990).

9. TSS / acid ratio.

\section{Statistical Analysis:}

Collected data were subjected to statistical analysis according to the methods described by Snedecor and Cochran (1989). Mean separation was done using Duncan multiple range test at $5 \%$ level (Duncan, 1958). Because of severe damage of stored fruits under the long tested storage period of 105 days regarding chilling injury index (more than $6.43 \& 6.23$ in the two seasons, respectively) and decay percentage (more than $76.4 \& 76.4$ in the two seasons, respectively), which don't permit to assess the other fruit quality parameters, the application of 105 days storage period was canceled during the statistical analysis respecting the majority of fruit quality parameters.

\section{RESULTS AND DISCUSSION}

\section{Discarded Fruits Attributes [chilling injury (CII) and fruit decay\% (FD \%)]}

\subsection{During cold storage}

Data in Table 1 indicate that CII and FD \% were gradually increased as cold storage period increased. The highest values of CII and FD \% were recorded in fruits stored for 105 days $(6.43 \& 6.23$ and $76.4 \& 76.4 \%$ for CII and FD \% in the first and second seasons, respectively).

All modified atmosphere (MA) treatments caused significant depressed CII. The least values resulted under effect of passive MA containing $25 \mathrm{~g}$ wetted 
$\mathrm{Ca}(\mathrm{OH})_{2}$ treatment (1.86 and 1.74 in the first and second seasons, respectively). While, MA treatments tended to significant increase in FD\% compared to control treatment (packing in plastic nets) in both seasons. Active MA treatments gave higher FD \% than passive MA without additions treatment. Passive MA containing $25 \mathrm{~g}$ wetted $\mathrm{Ca}(\mathrm{OH})_{2}$ treatment recorded the least FD \% values in first (21.2\%) and second (20.6\%) seasons as compare to most of the other tested MA treatments.

Interaction between cold storage periods and MA treatments was significant in the two seasons regarding $\mathrm{CII}$ and FD\%. Generally, prolonging the interacted cold storage period increased CII and FD under the same MA treatment. Thirty days cold storage period interacted with any of the five MA treatments recorded the least values of $\mathrm{CII}$ and $\mathrm{FD} \%$. While, the highest values came from the interaction between 105 days storage period with all tested MA treatments. This was confirmed during the two seasons.

\subsection{During shelf life}

Data in Table 2 also reveal that CII and FD \% during shelf life were significantly increased as cold storage period increased.

The effect of MA treatments during shelf life periods on CII and FD \% were significant effect in the two seasons. The least values of CII (2.31 and 2.36 for $1^{\text {st }}$ and $2^{\text {nd }}$ seasons, respectively) were recorded in fruits subjected to passive MA containing $25 \mathrm{~g}$ wetted $\mathrm{Ca}(\mathrm{OH})_{2}$ treatment comparing to control treatment and other MA treatments. While, the highest values came from active MA $10 \%$ $\mathrm{O}_{2}+3 \% \mathrm{Co}_{2}$ treatment during the two seasons. In addition, control treatment showed the least values of FD \% in the two seasons $(0.00 \%)$, while, passive MA without additions treatment recorded the highest values of FD \% in the two seasons (42.3 and $35.8 \%$, respectively).

As for interaction effect on CII and FD \% during shelf life, data of the same Table 2 indicates that shelf life fruits revealed similar trend as the above mentioned for interaction effects after cold storage.

The reductions in CI with MA treatments are in agreement with the results of Wardowsky et al., (1973) on limes and grapefruit; Meir et al., (1998) on Fuerte avocado ; Pesis et al., (2000) on mango and Porat et al., (2004) on citrus fruits.

Modified atmosphere tended to significant increase in FD \%. These results are in line with those obtained by Rygg and Wells (1962), they reported that plastic film may promote decay of lemon fruits because of high levels of humidity and $\mathrm{CO}_{2}$ within the sealed package. Ding et al., (2002) on loquat fruits stated that passive MA increased incidence of decay. However, packaging fruits in sealed polyethylene bags might be resulted in high moisture inside the sealed package leading to more increases in fruit decay especially without using any chemicals for rot control. 
2- Other Fruit Quality Attributes

2.1. Fruit weight loss percentage (FWL \%), peel color index (PCI) and pulp firmness

\subsubsection{During cold storage}

Data in Table 3 show that cold storage periods had significant effects on FWL $\%$ and PCI during the two seasons. The least values of FWL $\%$ and PCI $(5.67 \& 6.23 \%$ and $2.43 \& 2.48$ in the two seasons, respectively) came from 30 days cold storage, and then their values were increased with the advance of storage period up to 90 days.

All MA treatments caused significant decreases in FWL $\%$ and pulp firmness, while MA treatments increased PCI compared with control treatment in the two seasons. The least values of FWL $\%$ and better color resulted from passive MA treatments in the two seasons as compare to active MA or control treatments.

The interaction between cold storage period and MA treatments was significant in the two seasons in respect of FWL \%, PCI and pulp firmness. The least values of FWL \% came from the 30 days cold storage period interacted with passive MA without additions treatment, while, the highest values came from 60 or 90 days storage period without MA treatment in the two seasons. Fruits treated with active MA $10 \% \mathrm{O}_{2}+3 \% \mathrm{CO}_{2}$ treatment in the first season or passive MA with adding $25 \mathrm{~g}$ wetted $\mathrm{Ca}(\mathrm{OH})_{2}$ per sealed package treatment in the second one and stored for 30 days recorded that lowest values of PCI, while, better color of peel fruits obtained after 90 days with passive MA without additions treatment in the two seasons. The least values of firmness in the first season came from active MA $10 \% \mathrm{O}_{2}+3 \% \mathrm{CO}_{2}$ treatment after 90 and 60 days cold storage in the second season and the highest values came from 90 days with control treatment in the two seasons (Table 3).

\subsubsection{During shelf life}

Data in Table 4 show that FWL \% and PCI were significantly increased, while firmness of fruit pulp was significantly decreased during shelf life period as the cold storage period was increased (in the two seasons).

The tested MA treatments effects during shelf life period exhibited significant increases in FWL \% an oppositional with the cold storage period; PCI during shelf period revealed similar trend as that previously mentioned for during cold storage period. Fruit pulp firmness recorded significant increases under all MA treatments as compared with control treatment in the second season without significant differences between them, while in first season active $\mathrm{MA} 10 \% \mathrm{O}_{2}$ $+6 \% \mathrm{CO}_{2}$ treatment significantly reduced firmness of fruit pulp as compared to control treatment.

The interaction between cold storage period and MA treatments (Table 4) had significant effects in the two seasons in respect of FWL \% and PCI during 
shelf life period, and in most cases values of them were gradually increased with the advance of cold storage period, while, firmness of fruit pulp was significant in the first season only.

The reduction in FWL \% with MA treatments is in agreement with results of Pereira et al., (2004) on guava; Rocha et al., (2004) on apples; Martines-Romero et al., (2003) on table grapes; Harb et al., (2006) on cherries; Mortazavi et Al., (2007) on date fruits and Kudachikar et al., (2011) on 'Robusta' banana. The tested MA treatments effect during shelf life period caused significant increases in FWL $\%$. These results were in line with those reported by $(\mathrm{Gad}, 2008)$ on guava. The weight loss is a result of water loss from the fruit tissues and partially of the respiration process (Hussein et al. 1998). However, MA treatments does not directly influence the rate of water loss, but the need for a gas tight environment for MA storage and transport often results in significant increases in relative humidity around fruits and consequently reduced water loss compared to air storage (Kader, 1986). Such studies demonstrate that the high humidity obtained within the sealed packages significantly delayed fruit water loss.

Data showed that MA treatments recorded the highest PCI compared to control treatment and it was increased with the advance of cold storage period. These results are in agreement with those reported by Pereira et al., (2004) on guava; Rocha et al., (2004) on apples; Padilla-Zakour et al., (2004) and Harb et al., (2006) on cherries and Aday, et al., (2011) on strawberry. However, lime fruits are non-climacteric and prolonging cold storage period may stimulate analyses of green chlorophyll pigments permitting to appearance the yellow carotenoid pigments.

The reduction in fruit firmness with increasing cold storage period is agree with the results obtained by Viskelis et al., (2011) on apples. According to Hussein et al. (1998) rate of insoluble protopectins degradation to simple pectins was increased with the progress of storage perioid. Also, Pectinesterase activity is expected to increase progressively during storage and as a result decrease hardiness of fruit peel and pulp during storage, as reported by (Ponomarev, 1968) on pear. The loss of firmness is related to the degradation of the cellular wall by poligacturonasis and pectinametilesterasis enzymes and to the loss of water (Kays, 1991).

\subsection{Juice \%, juice TSS \% and juice Vit. C}

\subsubsection{During cold storage}

It is clear that Juice \% and juice TSS \% were gradually increased with advancing cold storage period and reached its maximum values $(33.7 \& 35.0 \%$ and $9.61 \&$ $9.93 \%$ ) after 90 days cold storage in the two seasons, respectively (Table 5). On the contrary, the uppermost values of juice Vit. C $(52.6 \& 56.1 \mathrm{mg} / 100 \mathrm{ml}$ juice in the two seasons, respectively) were obtained in the first sample (30 days storage period), the following storage periods revealed gradually decreases in Vit. 
$\mathrm{C}$ values in juice to reach the minimum values $(34.6 \& 35.6 \mathrm{mg} / 100 \mathrm{ml}$ juice in the two seasons) at the last sample (90 days) in both seasons.

Under MA treatments, control fruits had the highest Juice \% and juice TSS $\%(34.5 \& 36.9 \%$ and $10.0 \& 9.96 \%$ in the two seasons, respectively). While, the tested MA treatments caused significant decrease in Juice $\%$ and juice TSS \% comparing to control treatment with no significant difference between control and active MA $10 \% \mathrm{O}_{2}+6 \% \mathrm{CO}_{2}$ treatment in the first season. All MA treatments did not significantly affect on juice Vit $\mathrm{C}$ during both seasons.

The interaction effect between cold storage period and MA treatments (Table 5) was significant in the two seasons with Juice $\%$, juice TSS \% and juice Vit. C. In most cases, values of Juice $\%$ and juice TSS $\%$ were gradually increased with the advance in cold storage period, while, juice Vit. C was gradually decreased with the advance in cold storage period in the two seasons.

\subsubsection{During shelf life}

Data in Table 6 indicate that Juice \%, juice TSS \% and juice Vit. C during shelf life revealed a similar trend as that mentioned above for during cold storage. However, the effect of cold storage period during shelf life on TSS \% was significant in the second seasons only.

The tested MA treatments during shelf life period increased fruit Juice \%, but decreased values of juice TSS \% compared with control treatment. While, juice Vit. $\mathrm{C}$ was reduced by MA treatments without significant difference with passive MA without additions treatment and passive MA with adding $25 \mathrm{~g}$ wetted $\mathrm{Ca}(\mathrm{OH})_{2}$ per sealed package treatment in the second season (Table 6).

The interaction between cold storage period and MA treatments was significant in the two seasons with Juice $\%$ and juice TSS \% during shelf life period. Most values of Juice $\%$ and juice TSS $\%$ were gradually increased with increasing the interacted cold storage period. While, juice Vit. C did not significantly affected by all interaction treatments during the two seasons.

Modified atmosphere conditions decreased TSS values compared with control. While, TSS was increased with the advance of cold storage period. These results agree with those reported by Pal et al., (2005) and Gad, (2008) on guava ; Sora et al., (2006) on Andean blackberry and Kudachikar et al., (2011) on 'Robusta' banana.

The gradual increase in TSS \% with the increase of storage period could be due to: degradation of complex insoluble compounds, like starch, to simple soluble compounds, like sugars, leading to more TSS accumulation in fruits or to water loss through transpiration during storage period (Hussein et al., 1998).

Ascorbic acid content was decreased with advancing storage period. These results are in line with those obtained by EL-Hefnawi et al., (2008) on guava and Ahmed et al., (2007) on orange. As for MA effects, Viskelis et al., (2011) on apples reported that vitamin $\mathrm{C}$ content was decreased under MA treatments. 
However, the loss in ascorbic acid content during storage could be attributed to the rapid conversion of L- ascorbic acid into dihydrascobic acid in the presence of L- ascorbic acid oxidase (Hussein et al., 1998).

\subsection{Juice acidity \%, technological index (TI) and TSS / acid ratio \\ 2.3.1. During cold storage}

Juice acidity \% was gradually decreased with increasing cold storage period and reached its minimum values (6.12 and $6.25 \%$ ) after 90 days of cold storage in the two seasons, respectively. While, TI and TSS / acidity ratio were gradually increased with the advance in cold storage period and reached its maximum values ( $3.24 \& 3.48$ and $1.56 \& 1.60)$ after 90 days of storage in the two seasons, respectively (Table 7).

Data of the same Table 7 reveal that the tested MA treatments obviously depressed juice acidity\% as well as TI compared with control treatment without significant differences between MA treatments with juice acidity \% in most cases during the two experimental seasons. Oppositional, MA treatments significantly increased TSS / acidity ratio values compared with control treatment without significant between them in the second season.

Interaction treatments between cold storage and MA had significant effects in the two seasons with juice acidity $\%$ and TI. Generally, the highest values of juice acidity were recorded in fruits packed in control treatment and stored for any tested times (30, 60 or 90 days). While, the least acidity percentages were noticed in juice of fruits stored for 90 days and previously treated with passive or active MA. This was confirmed in the two seasons. As for TI, the maximum values (4.06 and 4.44) of TI resulted from interaction after 90 days cold storage period with control treatment, however, but the minimum values (2.00 and 1.99) were obtained after 60 days cold storage period interacted with active $\mathrm{MA} 10 \% \mathrm{O}_{2}+3 \% \mathrm{CO}_{2}$ treatment in the two seasons (Table 7).

\subsubsection{During shelf life}

Data in Table 8 indicate that fruits during shelf life fruits followed a similar trend as that mentioned for during cold storage treatments. This came true with the effect of duration of cold storage on juice acidity \%, TI and TSS / acidity ratio and MA treatments on juice acidity $\%$.

The effect of MA treatments on TI and TSS / acidity ratio during shelf life was significant without evident trend in both seasons (Table 8).

Also, data in the same Table 8 indicate the interaction between cold storage period and MA treatments was significant in the two seasons regarding to juice acidity $\%$, TI and TSS / acidity ratio. The highest values of juice acidity \%, TI and TSS / acidity ratio resulted from combination treatments of 30 days cold storage period with control treatment (8.57 and 8.30\%); 90 days cold storage period with passive MA without additions treatment (4.23 and 4.37) and 90 days 
cold storage period with passive MA with adding $25 \mathrm{~g}$ wetted $\mathrm{Ca}(\mathrm{OH})_{2}$ per sealed package treatment (1.56 and 1.53) in the two seasons, respectively. But, the lowest values for these parameters were gained after 90 days cold storage period with passive MA with adding $25 \mathrm{~g}$ wetted $\mathrm{Ca}(\mathrm{OH})_{2}$ per sealed package treatment (5.83 and 5.83\%); after 60 days cold storage period with active MA $10 \% \mathrm{O}_{2}+3 \% \mathrm{CO}_{2}$ treatment (2.83 and 2.83) and after 30 days cold storage period with passive MA without additions treatment (1.17 and 1.13) in the two seasons, respectively.

Juice acidity $\%$ was decreased with the advance of storage period. These findings are in line with Jitender et al., (2003) on guava and Sora et al., (2006) on Andean blackberry. Also it was decreased after shelf life with the advance of storage period. The results are in a good line with those obtained by EL-Hefnawi et al., (2008). All MA treatments caused significant reduction in juice acidity \% compared with control. Such results are contradicted with EL-Hefnawi et al., (2008) on guava and Ji Hua et al., (2011) on Black Diamond plums.

Decreasing acid \% during storage period might be due to destruction of organic acids through oxidation and their consumption in respiration processes within fruit tissues. Progress of storage period was found to raise respiration rate of the fresh fruits (Hussien et al., 1998).

Conclusively, obtained results of this study, make possible to recommend storage Balady lime fruits (in carton boxes at rate of $190 \pm 10 \mathrm{~g}$ fruits/ liter) under passive MA containing $25 \mathrm{~g}$ wetted $\mathrm{Ca}(\mathrm{OH})_{2}$ treatment for 60 days at $12 \pm 1^{\circ} \mathrm{C}$ and $90-95 \%$ relative humidity. Since, this combination treatment minimized fruits chilling injury and percentage of fruit decay during storage period as well as it make possible to maintain fruits in good quality for five days shelf life at supermarket conditions $\left(20^{\circ} \mathrm{C}\right.$ and $\left.60-70 \% \mathrm{RH}\right)$.

\section{REFERENCES}

Aday, M. S.; C. Caner and F. Rahva (2011). Effect of oxygen and carbon dioxide absorbers on strawberry quality. Postharvest Biology and Tech., 62 (2): 179-187.

Ahmed, D.M.; S.M. El-Shami and M.H. El-Mallah (2007). Jojaba oil as a novel coating for exported Valencia orange fruit. Part. 1: The use of trans (Isomerized) Jojaba oil. American Eurasian Journal of Agric. And Environmental Science, 2(2):173-181.

AOAC (1980). Association of Official Analytical Chemists. Association of Official Analytical Methods Chemists. 14 ${ }^{\text {th }}$ Ed., Published by Box.540 Washington 4DC, USA.

Artes-Hernandez , F.; F. A. Tomas-Barberan and F. Artes (2006). Modified atmosphere packaging preserves quality of $\mathrm{SO} 2$ - free 'Superior seedless' table grapes. Postharvest Biology and Tech., 39(2): 146-154. 
Chitarra, M.I. and A.B. Chitarra (1990). (Eds.), Po's-colheita de frutos ehortalic as: fisiologia e manuseio. ESAL/FAEPE, Lavras. [C. F. Ricardo A. K.; M. L. L. Jomori; A. P. Jacomino ; M. C. D. Vitti and M. Padula (2003). Intermittent warming in 'Tahiti' lime treated with an ethylene inhibitor. Postharvest Biology and Tech., 29: 195-203]

Ding C. K; K. Chachin; Y. Ueda; Y. Imahori and C. Y. Wang (2002). Modified atmosphere packaging maintains postharvest quality of loquat fruit. Postharvest Biol. Techno., 24: 341-348.

Duncan, D.B. (1958). Multiple range and Multiple F test. Biometrics, 11:1- 42.

El-Hefnawi, S.M.; S. A. Nomer; A. S. A. Hassan and M.M. Gad (2008). Effect of packaging during cold storage period on guava fruits $\mathrm{cv}$. ElMamoura. Egyptian J. of App. Sci., 23 (3):186-212.

Gad M. M (2008). Effect of some postharvest treatments on storage and shelf life of guava fruits. M. Sc. Thesis, Fac. Agric. Zagazig Univ. ARE.

Golias, J.; M. Fruhwirt and V.Mrazova (2010). Effects of modified atmospheric cool storage conditions on the quality of sweet cherries.

Mitteilungen Klosterneuburg, Rebe und Wein, Obstbau und Fruchteverwertung, 60(2): 278-286.

Harb, J., A. A. Saquet, R. Bisharat and J. Streif (2006). Quality and biochemical changes of sweet cherries cv. Regina stored in modified atmosphere packaging. Journal of Applied Botany and Food Quality, 80(2):145-149.

Hussein, A.M.; M.B. El-Sabrout and A.E. Zaghloul (1998). Postharvest physical and biochemical changes of common and late types of seedy guava fruits during storage. Alex. J. Agric. Res., 43(3): 187-204.

Ji Hua; Guan JunFeng; Feng YunXiao; Li LiMei and Sun YuLong (2011). Effect of MA package and prestorage on quality and browning of Black Diamond plums during cold storage. J. of Fruit Sci., 28(1): 147-150.

Jitender K; R.K. Sharama; R Singh and R.K. Goyal (2003). Effect of different types of polyethylene on shelf life of summer guava. Haryana $\mathrm{J}$. Hort. Science, 32 (3/4):201-202.

Kader, A.A. (1986). Biochemical and physiological basis for effects of controlled and modified atmosphere on fruits and vegetables. Food Tech., (May): 99-102.

Kays, S.J. (1991). Post Harvest Physiology And Handling Of Perishable Plant Products. Van Nostrand Reinhold, New York: AVI Book, 532p.

Kudachikar, V. B.; S. G. Kulkarni and M. N. K. Prakas (2011). Effect of modified atmosphere packaging on quality and shelf life of 'Robusta' banana (Musa sp.) stored at low temperature. J. Food Science and Tech., 48 (3): 319-324. 
Lucass, F.M. (1944). Determining ascorbic acid in large number of plant samples. Ind. Eng. Chem. Annual Ed., 15: 649-652.

Martines-Romero, D., F. Guillén, S. Castillo, D. Valero and M. Serrano (2003). Modified atmosphere packaging maintains quality of table grapes. Journal of Food Science., 68 (5): 1838-1843.

Meir, S.; D. Naiman; J. Y. Hyman; M. Akerman; G. Zauberman; Y. Fuchs; R. bielski; W. Laing and C. Clark (1998). Modified atmosphere packing enables prolonged storage of Fuerte avocado fruit. Acta-Hort., 464: 397-402.

Mortazavi, S. M. H., K. Arzani, and M. Barzegar (2007). Effect of vacuum and modified atmosphere packaging on the postharvest quality and shelf life of date fruits in khalal stage. Acta Hort. (ISHS), 736:471-477.

Padilla-Zakour, O. I., K. S. Tandon and J. M. Wargo (2004). Quality of modified atmosphere packaged 'Hedelfingen' and 'Lapins' sweet cherries. Hort. Tech., 14 (3):331-337.

Pal, R. K., M. S. Ahmed, S. K. Roy and M. Singh (2005). Influence of Storage environment, surface coating, and individual shrink wrapping on quality assurance of guava (Psidium guajava) fruits. Plant Foods for Human Nutrition (Formerly Qualitas Plantarum), 59(2): 67-72.

Pereira, L.M.; A. C. C. Rodrigues; C. I. G. L. Strantpoulos; V.C.A Junqueira, R. L. Gunha and M.D.Hubinger (2004). Influence of modified atmosphere packaging and osmotic dehydration on the quality maintenance of minimally processed guavas. J. Food. Sci., 69(4): 172-177.

Pesis E.; D. Aharoni; Z. Aharon; R Ben-Arie,; N. Aharoni and Y. Fuchs (2000). Modified atmosphere and modified humidity packaging alleviates chilling injury symptoms in mango fruit. Postharvest Biol. Technol., 19: 93-101.

Ponomarev, P.F. (1968). Changes in content of pectin and activities of pectolytic enzymes during ripening and storage of pears. Tovarovedenie, $\mathbf{3}$ : 6-10 [c.f. Fd. Sci Tech. Abst., 2(10): 1092, 1970].

Porat R.; B. Weiss; L. Cohen; A. Daus and N. Aharoni (2004). Reduction of postharvest rind disorders in citrus fruit by modified atmosphere packaging. Postharvest Biol. Tech., 33: 35-43

Rocha, A. M. C. N., M. G. Barreiro and A. M. M. B. Morais (2004). Modified atmosphere package for apple 'Bravo de Esmolfe'. Food Control, 15(1):61-64.

Rygg G. L. and A. W. Wells (1962). Experimental Storage Of California Lemons In Controlled Atmosphere. U.S. Dept. Agric. Market Serve. AMS-475, 11p.

Sanchez-Ballesta; M.T.,Y. Lluch; M.J. Gosalbes; L. Zacarias; A. Granell and M.T. Lafuente (2003). A survey of genes differentially expressed during long-term heat-induced chilling tolerance in citrus fruit. Planta, 218: $65-70$. 
Snedecor, G. W. and W. G. Chochran (1989). Statistical Methods. $6^{\text {th }}$ ed., Iowa State Univ., press Ames, Iowa, USA. pp: 953.

Sora, A.D., G. Fischer and R. Flórez (2006). Refrigerated storage of mora de Castilla (Rubus glaucus Benth.) fruits in modified atmosphere packaging. Agron. Colomb., 24 (2): 226-237.

Viskelis, P.; M. Rubinskiene;A. Sasnauskas; C. Bobinas and N. Kvikliene (2011). Changes in apple fruit quality during modified atmosphere storage. Journal of Fruit and Ornamental Plant Res., 19 (1): 155-165.

Wardowsky, W.F.; W. Grierson and G.J. Edwards (1973). Chilling injury of stored limes and grapefruit as affected by differentially permeable packaging films. Hort. Science, 8: 173-175.

\section{زيادة مدة تخزين ثمار الليمون البلاي بإستخدام بعض معاملات التعديل السلبي والنشط للجو الهوائي.}

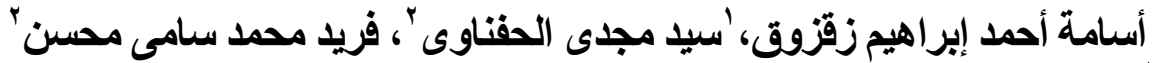

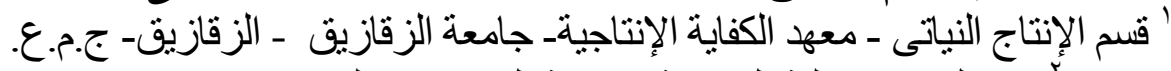

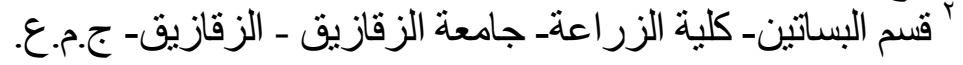

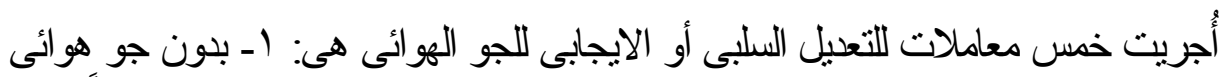

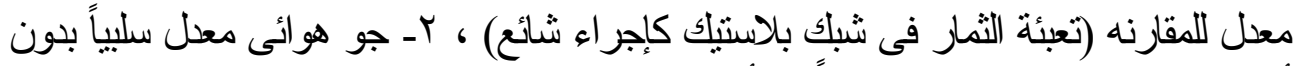

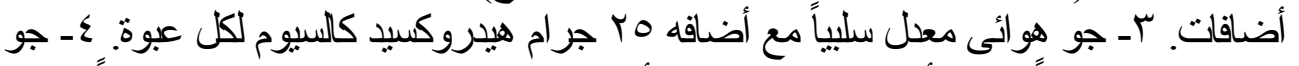

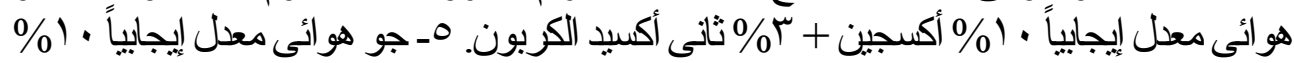

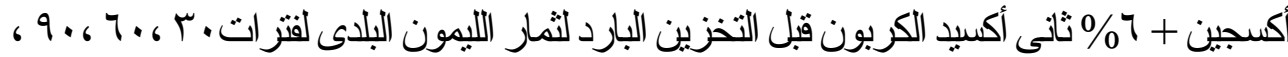

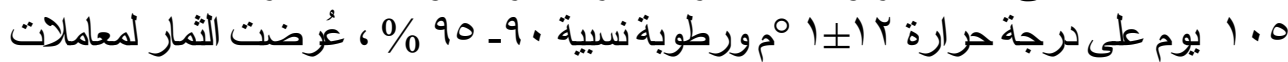

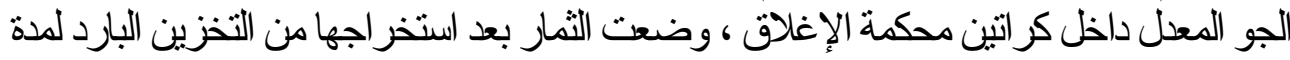

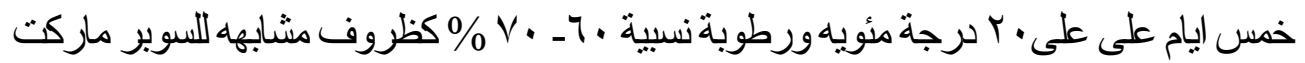

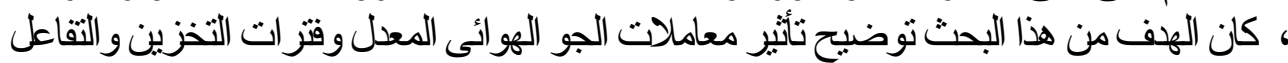

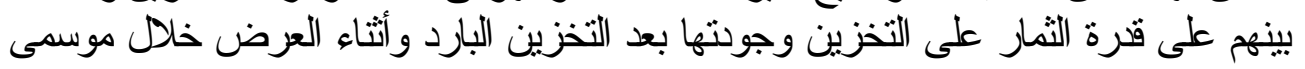
$r+11$ ، r.1.

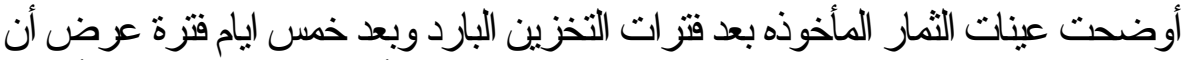

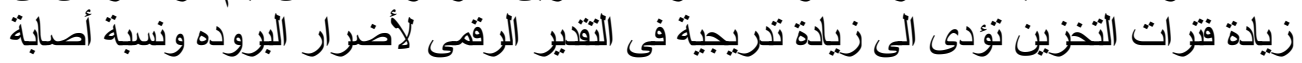

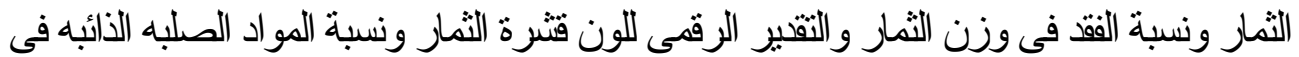

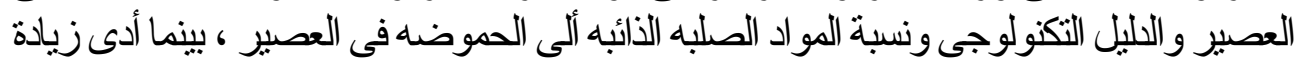


فتزة التخزين البارد الى انخفاض تريجي فى كل من محتوى الثمرة من العصير ومن فيتامين ج

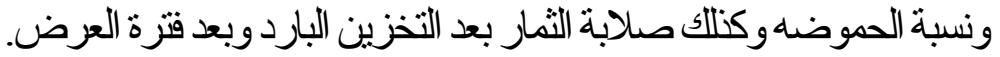

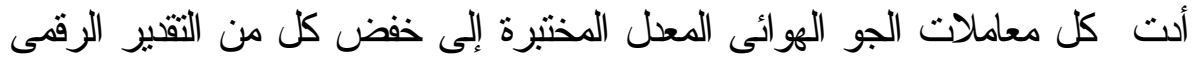

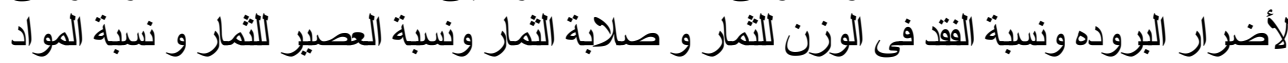

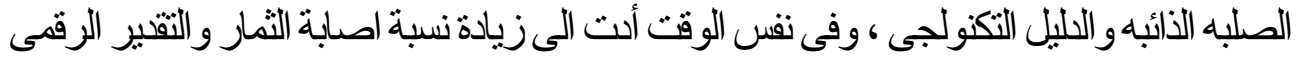

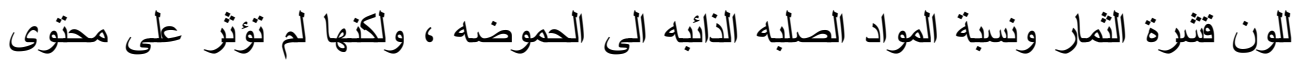
التوصية: التمار من فيتامينٍ ج. يمكن التوصية بتخزين ثمار اللبمون البلدى (داخل علب كرتون محكمة

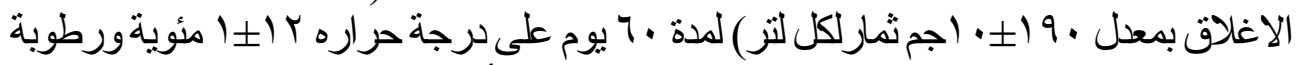

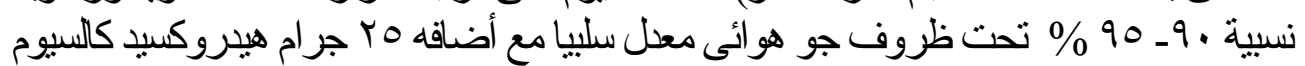

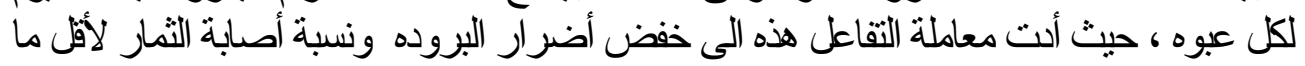

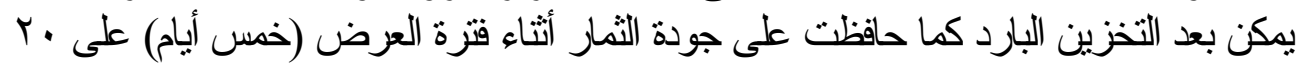

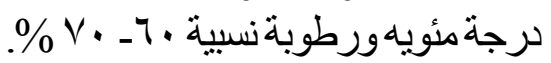

